\title{
Determinants of credit ratings: Evidence from panel discrete model
}

\author{
Zamira Oskonbaeva* \\ Kyrgyz-Turkish Manas University, Kyrgyzstan
}

Received: 19 July 2019

Revised: 19 February 2020

Accepted: 26 February 2020

\begin{abstract}
This study aims to explore how changes in explanatory variables may affect the probability of sovereign credit ratings assigned by Fitch, which is assumed to be a binary choice variable. For this purpose annual data of selected developed and developing countries for the period 20022016 have been used. In the empirical analysis the binary logit model has been applied. The estimation results indicate that all the explanatory variables are statistically significant in explaining credit ratings. Consistent with prior research, credit ratings are positively related to per capita gross domestic product, the level of economic development and export. In addition, credit ratings are negatively related to inflation, debt and default history. ${ }^{1}$
\end{abstract}

Keywords: sovereign credit ratings; binary logit model; credit rating agency; developed and developing countries; Fitch

JEL Classification Codes: G24, C23, G15, C5, E6

\section{Introduction}

Sovereign credit ratings play a considerable role in today's financial system. Sovereign credit ratings significantly impact the ability of public and private borrowers to access international capital markets (Mellios and Paget-Blanc, 2006). The credit scores taken by companies and countries significantly affect international borrowing costs. In other words, country credit ratings can complicate or ease countries' external financing opportunities. It should be noted that credit ratings reduce the adverse selection problems between borrowers and lenders (Kraft 2015a, 2015b). Sovereign ratings are crucial for developing economies, which have a greater susceptibility to rating announcements (Larrain et al., 1997). Credit rating agencies provide information to investors by measuring the degree of country risk. In other words, credit ratings

\footnotetext{
*E-mail: zamira.oskonbaeva@manas.edu.kg.

Citation: Oskonbaeva, Z. (2020) Determinants of credit ratings: Evidence from panel discrete model, Economics and Business Letters, 9(3), 240-247.
}

DOI: 10.17811/ebl.9.3.2020.240-247

\footnotetext{
${ }^{1}$ Previous version of this paper was presented in 19th International Symposium on Econometrics, Operations Research and Statistics held on October 17-20, 2018 in Antalya, Turkey.
} 
play a crucial role in attracting foreign direct investment. When making investment decisions, credit ratings assigned by credit rating agencies can be beneficial tools for potential investors.

There are three major rating agencies, Fitch, Moody's and S\&P. They control more than 90 $\%$ of the market. In order to assign a credit rating these agencies employ lots of quantitative and qualitative variables (Chee et al., 2015). So it is important to identify key determinants of sovereign ratings. This study aims to investigate how changes in key macroeconomic variables may influence the probability of sovereign credit ratings assigned by Fitch, which is assumed to be a binary choice variable. For this purpose annual data of selected developed and developing countries for the period 2002-2016 have been used.

The contribution of this study to the literature is twofold. First, it examines the significance of the fundamental variables used by the credit rating agencies in the assessment of sovereign ratings. Country-specific qualitative variables (development level of countries and crisis), were integrated into analysis along with macroeconomic (GDP per capita, inflation, export and debt) variables. Second, because of the discrete nature of ratings, the effect of these variables on ratings is assessed through binary logit model.

The rest of the paper is organized as follows. In Section 2 the previous literature dealing with this topic is briefly summarized. In Section 3 variables and data set are described. In Section 4 the principle issues concerning the methodology applied in the analysis are explained. Empirical results are given in Section 5. Finally the study concludes with a summary of key findings and recommendations in Section 6.

\section{Literature}

A large body of literature has explored the determinants of sovereign credit ratings. An empirical literature has emerged with the seminal work of Cantor and Packer (1996). Authors investigate the determinants of sovereign credit ratings by Moody's and S\&P as of September 29, 1995 using a cross-section of 49 countries. By applying OLS methodology, they report that their model with eight macroeconomic variables could explain more than $90 \%$ of the variability of the sovereign credit ratings. Authors examined the determinants of ratings and concluded that six variables (per capita income, GDP growth, inflation, external debt, level of economic development and default history), are likely to explain the ratings. Similar to Cantor and Packer (1996), Eliasson (2002) in the case of 38 countries found that the same macroeconomic variables explain a significant part of the model. Bozic and Magazzino (2013) based on a sample of 139 countries provided evidence that per capita gross national income, inflation, unemployment, fiscal balance, government debt and default history significantly affect ratings. Teixeira et al. (2018), using panel data of 86 countries for 1993-2013, concluded that a set of macroeconomic, external, government and qualitative factors play an important role on sovereign credit ratings. Mulder and Perrelli (2001) focused on a set of emerging market economies and found that the ratio of investment to GDP has the most significant impact on rating changes across countries. Bissoondoyal-Bheenick (2005) found that GNP per capita and inflation are the most significant determinants of ratings. Haque et al. (1998) concluded that economic variables play a key role in determining a country's ratings and political variables have no explanatory power. Unlike Haque et al. (1998), Butler and Fauver (2006) focused on a set of 86 countries and concluded that legal environment's marginal effect in sovereign credit ratings is much stronger than macroeconomic variables. In their study Archer et al. (2007) using a sample of 50 countries provided evidence that all political variables except from executive political tenure are insignificant. Afonso et al. (2007) implement the panel data ordered probit model. They conclude that per capita GDP/income, GDP growth rate, external debt to GDP, level of economic development, and inflation are the typical determinants of sovereign credit ratings. It can be observed that in early studies a linear regression model was used in which the 
Table 1. Variables.

\begin{tabular}{|c|c|c|}
\hline Variables & Abbreviation & Description \\
\hline $\begin{array}{l}\text { Per capita gross } \\
\text { domestic product }\end{array}$ & GDP & Per capita gross domestic product $(2010=100)$. \\
\hline Inflation & Inflation & The GDP price deflator. \\
\hline Export/GDP & Export & Export as a $\%$ of GDP. \\
\hline Debt/GDP & Debt & Government gross debt as a $\%$ of GDP. \\
\hline Default history & Crisis & $\begin{array}{l}\text { Dummy variable that takes value } 1 \text { for the country } i \text { in the } \\
\text { period of default and all successive periods, and zero otherwise. }\end{array}$ \\
\hline $\begin{array}{l}\text { Level of economic } \\
\text { development }\end{array}$ & DEV & $\begin{array}{l}\text { Dummy variable that takes value } 1 \text { for the developed country } \\
\text { and zero otherwise. }\end{array}$ \\
\hline
\end{tabular}

dependent variable credit rating was transformed to a linear scale (Afonso, 2003; Alexe et al., 2003; and Butler and Fauver, 2006). Recent studies began to employ probit models (Afonso et al., 2007; Afonso et al., 2009; Afonso et al., 2011; Gültekin-Karakaş et al., 2011; Brůha et al., 2017; Teixeira et al., 2018). Based on the above literature this study aims to fill the gap by examining credit ratings with panel discrete model.

\section{Dataset and variables}

In this study annual data of selected 40 developed and developing countries for the period 20022016 have been used. According to Fitch rating classification, there are twenty one possible credit ratings for a country: AAA being the highest rank that a country can get and $\mathrm{C}$, the lowest. A rating between $\mathrm{AAA}$ and $\mathrm{BBB}$ signals a good investment environment for a country, whereas any rating between $\mathrm{BB}$ and $\mathrm{C}$ is speculative. When studies in the literature are examined, it is seen that the factors affecting the credit rating are generally GDP per capita, GDP growth rate, foreign trade indicators, crisis and development level of the country (Canuto et al., 2004; Cantor and Packer, 1996). Building on the evidence provided by the existing literature the following macroeconomic variables incorporated in the model: per capita GDP, inflation, export/GDP, debt/GDP, default history and level of economic development. All the data have been collected from World Bank, International Monetary Fund databases and Fitch website. The description of the variables used in the study are given in Table 1.

The sample consists of 560 observations of average sovereign credit ratings, across 40 countries, grouped in 6 regions, from 2002 to 2016. List of countries used are displayed in Table 2.

The model used can be written as:

$$
\begin{gathered}
\text { Ratings }_{i t}=\alpha_{1}+\alpha_{2} \text { GDP }_{i t}+\alpha_{3} \text { Export }_{i t}+\alpha_{4} \text { Crisis }_{i t}+\alpha_{5} \text { Inflation }_{i t} \\
+\alpha_{6} \text { Debt }_{i t}+\alpha_{7} D E V+\varepsilon_{i t}
\end{gathered}
$$

where Ratings is dependent variable and GDP, Export, Crisis, Inflation, Debt and level of Development are explanatory variables. Rating is the binary variable equal to 1 for countries with investment grade status and as 0 otherwise. The selection of the explanatory variables, which are included in logit model is based on the previous literature and the data attainability of the countries.

\section{Methodology}

\subsection{Panel logit model}

The panel logit models are one of the binary choice models which are used to solve the problems encountered in the linear probability model. With these models, estimates are made when it is desired to examine nonlinear relationship between probability and explanatory variables. Panel logit models have a logistic cumulative distribution function as below (Güriş, 2015): 
Table 2. List of countries used.

\begin{tabular}{|c|c|c|c|c|c|}
\hline Region & $\begin{array}{l}\text { Number of } \\
\text { countries }\end{array}$ & Region & $\begin{array}{l}\text { Number of } \\
\text { countries }\end{array}$ & Region & $\begin{array}{l}\text { Number of } \\
\text { countries }\end{array}$ \\
\hline Africa & 3 & Hong Kong & & \multirow{14}{*}{$\begin{array}{l}\text { France } \\
\text { Greece } \\
\text { Hungary } \\
\text { Iceland } \\
\text { Ireland } \\
\text { Italy } \\
\text { Latvia } \\
\text { Lithuania } \\
\text { Portugal } \\
\text { Romania } \\
\text { Slovenia } \\
\text { Spain } \\
\text { Ukraine } \\
\text { United Kingdom }\end{array}$} & \\
\hline Egypt & & India & & & \\
\hline South Africa & & Japan & & & \\
\hline Tunisia & & Kazakhstan & & & \\
\hline North America & 1 & Lebanon & & & \\
\hline United States & & Philippines & & & \\
\hline \multirow{7}{*}{$\begin{array}{l}\text { Latin America } \\
\text { Brazil } \\
\text { Chile } \\
\text { Colombia } \\
\text { Costa Rica } \\
\text { El Salvador } \\
\text { Peru }\end{array}$} & \multirow{7}{*}{6} & Russia & & & \\
\hline & & Thailand & & & \\
\hline & & Turkey & & & \\
\hline & & Oceania & 2 & & \\
\hline & & Australia & & & \\
\hline & & Indonesia & & & \\
\hline & & Europe & 17 & & \\
\hline Asia & \multirow[t]{2}{*}{11} & Bulgaria & & & \\
\hline $\begin{array}{l}\text { Azerbaijan } \\
\text { China }\end{array}$ & & $\begin{array}{l}\text { Czech Republic } \\
\text { Estonia }\end{array}$ & & $\begin{array}{l}\text { Total of } \\
\text { countries }\end{array}$ & 40 \\
\hline
\end{tabular}

$$
F\left(\dot{\beta} x_{i t}\right)=\frac{e^{\dot{\beta} x_{i t}}}{\left(1+e^{\dot{\beta} x_{i t}}\right)}
$$

According to the relationship existing between the unobserved, individual specific hetereogeneity and the vector of regressors it can be employed either random or fixed effects models. One undesirable feature of the fixed effect model is that the maximum likelihood estimator becomes inconsistent, while in the random effects model powerful assumptions regarding heterogeneity should be made (Green, 2011).

In the random effect logit model conditional probability of the event is calculated as following:

$$
\begin{gathered}
P\left(y_{i t}=1 \mid \mu_{i}\right)=F\left(\mu_{i}+\dot{\beta} x_{i t}\right) \\
P\left(y_{i t}=1 \mid \mu_{i}\right)=\frac{1}{\left(1+e^{-\left(\mu_{i}+\dot{\beta} x_{i t}\right)}\right.}
\end{gathered}
$$

The probability of an occurrence of analyzed event is calculated as follows:

$$
\begin{gathered}
P\left(y_{i} \mid x_{i}\right)=\int P\left(y_{i} \mid x_{i}, \mu_{i}\right) f\left(\mu_{i}\right) d \mu_{i} \\
P\left(y_{i} \mid x_{i}, \mu_{i}\right)=\prod_{t} P\left(y_{i} \mid x_{i}, \mu_{i}\right)
\end{gathered}
$$

where $\mu_{i}$ refers to an individual effect.

\section{Empirical results}

The structure of the frequency distributions of the major variables included in this study are displayed in Table 3. Descriptive statistics are provided to explain the fundamental features of the data used in this analysis. Ratings, development and crisis were not analyzed quantitatively as they are binary variables.

The results of the descriptive statistics indicate that the mean value of all variables are greater than the median value, implying that the distribution of these variables are positively skewed. It can also be observed from the positive measures of skewness. The above descriptive tables 
Table 3. Descriptive statistics.

\begin{tabular}{lrrrr}
\hline \hline Statistics & GDP & Export & Debt & Inflation \\
\hline Min & 801.508 & 9.0375 & 0.1 & 27.5095 \\
Max & 69974.1 & 221.61 & 236.3 & 359.773 \\
SD & 15796.05 & 31.2637 & 43.50882 & 48.3472 \\
Mean & 17439.31 & 42.0291 & 53.9023 & 109.9002 \\
p50 & 10641.6 & 31.9357 & 41.55 & 100 \\
Skewness & 0.9999 & 2.9299 & 1.5927 & 2.2581 \\
Kurtosis & 2.7240 & 14.4532 & 5.9735 & 9.3311 \\
\hline \hline
\end{tabular}

Table 4. Panel logit model estimation.

\begin{tabular}{lrr}
\hline \hline Variables & Coefficient & Standard Error \\
\hline Constant & $-118.3327 * * *$ & 19.5639 \\
GDP & $19.4956 * * *$ & 2.7384 \\
Export & $6.5871 * * *$ & 2.5007 \\
Crisis & $-13.1971 * * *$ & 3.1041 \\
Inflation & $-4.1322 * * *$ & 1.1939 \\
Debt & $-4.5119 * * *$ & 1.1400 \\
Development & $14.0998 * *$ & 6.7966 \\
\hline Log likelihood & -109.1578 & \\
Number of obs & 560 & \\
\hline \hline
\end{tabular}

Note: $* * *, * *$ and $*$ indicates statistical significance at the $1 \%, 5 \%$ and $10 \%$ level.

Table 5. The marginal effects for the Logit model.

\begin{tabular}{lrr}
\hline \hline Variables & Coefficient & Standard Error \\
\hline GDP & $19.4956^{* * *}$ & 2.7384 \\
Export & $6.5871^{* * *}$ & 2.5007 \\
Crisis & $-13.1971^{* * *}$ & 3.1041 \\
Inflation & $-4.1322^{* * *}$ & 1.1939 \\
Debt & $-4.5119^{* * *}$ & 1.1400 \\
Development & $14.0998^{* *}$ & 6.7966 \\
\hline \hline
\end{tabular}

Note: $* * *, * *$ and $*$ indicates statistical significance at the $1 \%, 5 \%$ and $10 \%$ level.

reveal that the GDP varies in between 801.508 to 69974.1 with standard deviation 15796.05. The average export is 42.0291 and it lies between 9.0375 to 221.61 . The average rate of debt is 53.9023 and it varies from 0.1 to 236.3 in this period. The average inflation rate was 109.9002 and it varies from 27.5095 to 359.773 .

The results of binary logit model are reported in Table 4 .

According to the results obtained it can be concluded that all the coefficients are consistent in accordance with theoretical expectations and all variables are significant in explaining the dependent variable. The coefficients of inflation, debt and dummy variable default history are negative, whereas, the coefficient of per capita gross domestic product, export and dummy variable level of development are positive. The marginal effects for the logit model are displayed in Table 5.

Results summarized in Table 5 indicate that a 1 percent increase in per capita GDP will increase the probability of being investment grade country by 19 percent. It should be noted that per capita gross domestic product has a greater marginal impact on sovereign credit ratings compared with other variables. This result corroborates with the findings of Bozic and Magazzino (2013), Afonso et al. (2011) and Rowland (2004). Similarly a 1 percent increase in 
export will increase the probability of being in investment grade country by 6 percent. This result is consistent with the findings of Afonso et al. (2011), Jaramillo (2010) and Rowland (2004). The results revealed that if the country has a default history it has less chance of being in the investment grade country. Similar findings were reported by Cantor and Packer (1996), Mellios and Paget-Blanc (2006), Depken et al. (2011) Butler and Fauver (2006). A 1 percent increase in inflation will decrease the probability of being in investment grade country by 4 percent. This effect reflects the fact that countries with higher levels of inflation are less likely to get a better rating. The negative relation between inflation and rating has been previously obtained by Bissoondoyal-Bheenick (2005), Cantor and Packer (1996), Mellios and PagetBlanc (2006), Depken et al. (2011), Erdem and Varli (2014) and Teixeira et al. (2018). A 1 percent increase in debt will decrease the probability of being in investment grade country by 4 percent. The higher the country's debt, the more vulnerable it became to default and liquidity problems. This result is in accordance with the empirical evidence of Mellios and Paget-Blanc (2006), Jaramillo (2010), Afonso et al. (2011) and Teixeira et al. (2018). The results also indicate that development dummies have an important influence on credit ratings. If the country is developed it has more chance of being in the investment grade country. This finding is in line with the evidence of Afonso (2003) and Cantor and Packer (1996).

\section{Conclusion}

This study aims to investigate how changes in explanatory variables may influence the probability of sovereign credit ratings assigned by Fitch. Binary logit model has been employed to the balanced panel data of 40 selected countries from 2002 to 2016.

The results indicate that all the explanatory variables are statistically significant in explaining credit ratings. In other words the coefficients have the correct signs as expected. Consistent with prior research, credit ratings are positively related to per capita gross domestic product, the level of economic development and export. In addition, credit ratings are negatively related to inflation, debt and default history.

According to the results obtained it can be concluded that the determinants of sovereign credit ratings can help sovereigns to better understand the drivers of their credit rating. The results can be useful for researchers, financial investors and governments which are interested in credit ratings. The findings of this study have several implications for market players and policymakers too. As a suggestion for future studies, different variables may be included and a wider time span can also be studied to explore credit ratings.

\section{Acknowledgements}

I thank the Editor-In-Chief Francisco J. Delgado and two anonymous reviewers whose comments/suggestions helped to improve and clarify this manuscript.

\section{References}

Alexe, S. Hammer, P. L., Kogan, A., and Lejeune, M.A. (2003) A non-recursive regression model for country risk rating, Rutcor Research Report 9, Rutgers Center for Operational Research, March.

Archer, Candace C., Glen Biglaise, and Karl DeRouen Jr. (2007) Sovereign bonds and the democratic advantage: does regime type affect credit rating agency ratings in the developing world?, International Organization: 61, Spring, pp. 341-365.

Afonso, A. (2003) Understanding the determinants of sovereign debt ratings: evidence for the two leading agencies, Journal of Economics and Finance, 27 (1), 56-74. 
Afonso, A., Gomes, P. and Rother, P. (2007) What 'hides' behind sovereign debt ratings?, European Central Bank Working Paper 711.

Afonso, A., Gomes, P., and Rother, P. (2009) Ordered response models for sovereign debt ratings, Applied Economics Letters, 16(8), 769-773.

Afonso, A., Gomes, P., and Rother, P. (2011) Short and long-run determinants of sovereign debt credit ratings, International Journal of Finance and Economics, 16(1), 1-15.

Bissoondoyal-Bheenick, E. (2005) An analysis of the determinants of sovereign ratings, Global Finance Journal, 15(3), 251-280.

Butler, A. W., and Fauver, L. (2006) Institutional environment and sovereign credit rating, Financial Management, 35 (3), 53-79.

Bozic, V., and Magazzino, C. (2013) Credit rating agencies: the importance of fundamentals in the assessment of sovereign ratings, Economic Analysis and Policy, 43 (2), 157-176.

Brůha, J., Karber, M., Pierluigi, B., Setzer, R. (2017) Understanding sovereign rating movements in euro area countries, European Central Bank Working Paper Series, No 2011.

Cantor, R. and Packer, F. (1996) Determinants and impact of sovereign credit ratings, Economic Policy Review, 2, 37-53.

Canuto, O., P. F. P. dos Santos, and P. C. de Sá Porto. (2004) Macroeconomics and Sovereign Risk Ratings. Paper presented at a seminar at the School of Economics, Business, and Accounting, University of São Paulo, São Paulo, Brazil, January.

Chee, S.W., Fah, C.F., and Nassir, A. M. (2015) Macroeconomics determinants of sovereign credit ratings, International Business Research, 8(20), 2-50.

Depken, C., LaFountain, C., and Butters, R. (2011) Corruption and creditworthiness: evidence from sovereign credit ratings, in Sovereign debt: From safety to default, ed. by R. Kolb, John Wiley \& Sons, Inc., Hoboken, NJ, USA.

Eliasson, A. C. (2002) Sovereign credit ratings, Working Paper No. 02-1. Deutsche Bank Research.1-23.

Erdem, O., and Varl, Y. (2014) Understanding the sovereign credit rating of emerging markets, Emerging Market Review, (20), 42-57

Fitch (2017) Available via https://www.fitchratings.com/site/home, accesed on 25.02.2017.

Greene, W.H. (2011) Econometric Analysis, 7th Edition, Prentice Hall.

Güriş S. (2015) Stata ile Panel veri Modelleri, Der Kitabevi Yayınevi, İstanbul.

Gültekin Karakaş, D., Hisarciklilar, M., and Öztürk, H. (2011) Sovereign risk ratings: biased toward developed countries?, Emerging Markets Finance \& Trade , (47), 69-87.

Haque, U. N., Mark, N. C. and Mathieson, D. J. (1998) The relative importance of political and economic variables in creditworthiness ratings (April 1998), IMF Working Paper,1-13. Available at SSRN: https://ssrn.com/abstract=882300.

IMF (2019) IMF database, available via https://www.imf.org/external/datamapper/datasets/ GDD (10.02.2020)

Jaramillo, L. (2010) Determinants of Investment Grade status in Emerging Markets, IMF Working Paper 10/117.

Kraft, P. (2015a) Do rating agencies cater? evidence from rating-based contracts, Journal of Accounting and Economics, 59, 264-283.

Kraft, P. (2015b) Rating agency adjustments to GAAP financial statements and their effect on ratings and credit spreads, The Accounting Review, 90, 641-674.

Larrain G., Reisen H. and von Maltzan J. (1997) Emerging market risk and sovereign credit ratings, OECD Development Center, 1-30.

Mellios, C., and Paget-Blanc, E. (2006) Which factors determine sovereign credit ratings?, The European Journal of Finance, 12(4), 361-377. 
Mulder, C., and Perrelli R. (2001) Foreign currency credit ratings for emerging market economies:IMF Working Paper 01/191, November 2001 (Washington: International Monetary Fund).

Rowland, P. (2004). Determinants of spread, credit ratings and creditworthiness for emerging market sovereign debt: a follow-up study using pooled data analysis, Banco de la Republica de Colombia, Borradores de Economia, 295.

Teixeira, J.C.A., Silva, F.J.F., Ferreira, M.B.S., and Vieira, J.A. C. (2018) Sovereign credit rating determinants under financial crises, Global Finance Journal, 36, 1-13.

World Bank (2018) Available via http://data.worldbank.org/country/, accesed on 25.05.2018. 